\title{
Implementasi Perubahan Kelembagaan Pelayanan Terpadu dalam Merespon Kebijakan Pemerintah Pusat
}

\section{The Implementation Of Change Institutional Integrated Services In Responding To Central Government Policy}

\author{
Ardiyati \\ Ilmu Pemerintahan,Fakultas Ilmu Sosial dan Ekonomi, \\ Universitas AMIKOM Yogyakarta \\ ardiyati@amikom.ac.id
}

\begin{abstract}
Abstrak
Bentuk kelembagaan merupakan faktor penting yang berpengaruh terhadap kinerja lembaga pelayanan terpadu satu pintu. Bentuk kelembagaan pelayanan terpadu diatur menurut kemampuan daerah. Meskipun begitu kebijakan pemerintah pusat juga mempunyai pengaruh signifikan terhadap perubahan kelembagaan daerah. Tujuan penelitian ini adalah mengetahui sejauhmana implementasi Peraturan Menteri Dalam Negeri Nomor 100 tahun 2016 tentang Pedoman Nomenklatur Dinas Penanaman Modal dan Pelayanan Terpadu berpengaruh terhadap terwujudnya proses kelembagaan pelayanan terpadu satu pintu di Kabupaten Bantul. Metode penelitian yang digunakan adalah kualitatif deskriptif. Hasil penelitian menunjukkan kebijakan pemerintah pusat melalui Peraturan Menteri Dalam Negeri Nomor 100 tahun 2016 tentang Pedoman Nomenklatur Dinas Penanaman Modal dan Pelayanan Terpadu mendorong adanya perubahan nomenklatur Dinas Perijinan Terpadu Kabupaten Bantul (DPT) berubah menjadi Dinas Penanaman Modal dan Pelayanan Terpadu (DPMPT). Terjadi peningkatan kewenangan lembaga dari sekedar sharing kewenangan proses perijinan permodalan dan investasi menjadi mempunyai kewenangan penuh dalam memproses dan monitoring evaluasi. Peningkatan kewenangan tersebut tidak disertai dengan perubahan pada nomenklatur kelembagaan, peningkatan kewenangan terkait dengan perijinan investasi, penambahan bidang dan seksi terkait investasi dan informasi. Peningkatan kewenangan pengolaan ijin investasi tersebut tidak diikuti dengan penambahan ijin yang dikelola dan sumber daya manusia lembaga pelayanan terpadu. Kebijakan perubahan nomenklatur lembaga pelayanan terpadu dengan peningkatan kewenangan perumusan kebijakan dan pelaksanaan dalam penanaman modal berhasil dalam mempercepat proses perijinan penanaman modal. Disisi lain beban kerja ini dirasakan terlalu berat tanpa penambahan sumber daya dinas.
\end{abstract}

\section{Kata Kunci: Implementasi, Pelayanan Terpadu, Kelembagaan}

\begin{abstract}
The structure of institutional integrated is an important factor that affects the performance of one-stop integrated service agency. The institutional structure of integrated services is regulated according to regional capability. However, central government policy also has a significant influence on regional institutional change. The purpose of this study is to know how far the implementation of the Minister of Home Affairs Regulation No. 100 of 2016 on
\end{abstract}


the Guidelines Nomenclature of Investment and Service Integrated Service affects the realization of one-door integrated service institutional process in Bantul regency. The research method used is qualitative descriptive. The results of the research indicate that the central government's policy through the Regulation of the Minister of Home Affairs Number 100 of 2016 on the Nomenclature Guidelines of the Investment Service and Integrated Service encourages the change of nomenclature of the Integrated Licensing Service of Bantul Regency (DPT) to become the Investment and Integrated Service Office (DPMPT). There is an increase in the authority of the institution from just sharing the authority of the capital and investment licensing process to have full authority in processing and monitoring the evaluation. The increase in authority is not accompanied by changes to the institutional nomenclature, increased authority related to investment licensing, the addition of investmentrelated sectors and sections and information. The increase in the authority of the investment permit management is not followed by the addition of managed licenses and human resources of integrated service agencies. The policy of change of nomenclature of integrated service agency with improvement of authority of policy formulation and implementation in investment succeed in accelerating process of permit of capital investment. On the other hand this workload is felt too heavy without the addition of official resources.

\section{Keywords: Implementation, Integrated Service, Institutional}

\section{A. Pendahuluan}

Pelayanan perijinan merupakan salah satu dari bentuk pelayanan publik yang dilakukan oleh pemerintah. Pelayanan perijinan menjadi salah satu tolak ukur kinerja pemerintah karena bersentuhan langsung dengan masyarakat. Proses pelayanan perijinan yang melibatkan berbagai instansi pemerintah daerah menjadi tolak ukur pencapaian good governance pemerintah daerah.

Salah satu permasalahan yang dirasakan oleh masyarakat saat mengakses pelayanan perijinan dan adalah ketidakjelasan informasi, pungutan liar, pelayanan yang lama tanpa kepastian, persyaratan yang rumit, dsb. Kondisi tersebut mendorong mendorong pemerintah memunculkan program penyelenggaraan pelayanan terpadu. Dasar hukum pelayanan publik adalah:

1) UU No. 25 Tahun 2007 tentang Penanaman Modal
2) Undang-undang Nomor 25 tahun 2009 tentang Pelayanan Publik

3) PP Nomor 96 Tahun 2012 tentang Pelaksanaan UU No.25 tentang Pelayanan Publik

4) Peraturan Presiden No. 97 tahun 2014 Penyelenggaraan Pelayanan Terpadu Satu Pintu

5) Peraturan Menteri Dalam Negeri Nomor 100 Tahun 2016 tentang Pedoman Nomenklatur Dinas Penanaman Modal dan Pelayanan Terpadu Satu Pintu.

Peraturan Presiden Republik Indonesia Nomor 96 tahun 2012 tentang pelayanan terpadu pada pasal 14 ayat menjelaskan bahwa sistem pelayanan terpadu dapat dilaksanakan melalui sistem pelayanan terpadu satu pintu; dan atau sistem pelayanan terpadu satu atap. Penelitian dari Kriswantoro (2012) memperlihatkan bahwa pelayanan perizinan di Kota Yogkarta dilaksanakan oleh lembaga 
berbentuk Dinas yaitu Dinas Perizinan Kota Yogyakarta. Strategi pelayanan satu pintu (one stop service) menggunakan dua pola yaitu pola pelayanan terpadu pintu dan pelayanan terpadu satu atap. Salah satu temuan penting dari studi tersebut adalah adanya kecemburuan antara dinas di lingkungan Pemerintah Kota Yogyakarta terhadap Dinas Perizinan yang diberikan kewenangan melayani soal perizinan.

Munculnya peraturan menteri dalam negeri nomor 100 tahun 2016 menegaskan tentang nomenklatur sistem pelayanan terpadu dengan bentuk Dinas Penanaman Modal dan Pelayanan Terpadu Satu Pintu. Ini berarti setiap lembaga pelayanan terpadu harus mengelola urusan penanaman modal dan pengembangan investasi. Nomenklatur dan bentuk kelembagaan pelayanan terpadu dan penanaman modal adalah Dinas Penanaman Modal dan Pelayanan Terpadu Satu Pintu.

Peraturan Presiden Republik Indonesia Nomor 97 tahun 2004 tentang penyelenggaraan pelayanan terpadu satu pintu menegaskan bahwa penyelenggaraan pelayanan terpadu satu pintu (PTSP) dilakukan oleh pemerintah kabupaten kota. Jangka waktu pelayanan terpadu ditetapkan paling lama 7 hari sejak diterimanya dokumen . Penyelenggaraan pe Penyelenggaraan Pelayanan wajib menggunakan Perizinan Secara Elektronik (PSE). PSE mencakup aplikasi otomatisi proses kerja (business process) dan informasi yang diperlukan dalam pelayanan.
Peraturan Menteri Dalam Negeri Nomor 100 Tahun 2016 tentang Pedoman Nomenklatur Dinas Penanaman Modal dan Pelayanan Terpadu Satu Pintu. Peraturan ini berfokus tentang nomenklatur lembaga pelayanan terpadu adalah Dinas Penanaman Modal dan Pelayanan Terpadu Satu Pintu (PTSP). Dalam peraturan tersebut juga mengklasifikasi tipelogi dinas yang bisa dipilih sesuai dengan kondisi daerah. Besaran tipelogi lembaga Dinas Penanaman Modal dan Pelayanan Terpadu Satu Pintu terdiri atas 4 macam yaitu:

1) Tipe A terdiri atas 1 (satu) secretariat dan papling banyak 8 (delapan) bidang, yang meliputi 4 (empat) bidang untuk melaksanakan fungsi penanaman modal dan 4 ( empat bidang untuk melaksanakan fungsi penanaman modal dan 4 bidang untuk melaksanakan fungsi PTSP.

2) Tipe $B$ terdiri atas 1 (satu) secretariat dan paling banyak 6 bidang, yang meliputi 3 bidang untuk melaksanakan fungsi penanaman modal 3 bidang untuk melaksanakan fungsi PSTP.

3) Tipe $C$ terdiri atas satu sekretariat dan paling banyak 4 bidang, yang meliputi 2 bidang untuk melaksanakan fungsi penanaman modal dan 2 bidang PTSP.

4) Tipe $C$ dengan nilai pemetaan kurang dari 401 (empat ratus satu), terdiri atas 1 (satu) terdiri atas 1 (satu) secretariat dan paling banyak 3 bidang, yang meliputi satu bidang untuk melaksanakan fungsi penanaman modal dan 2 bidang untuk melaksanakan fungsi PTSP.

Kebijakan pemerintah pusat pada masa pemerintahan Presiden Joko Widodo berfokus pada perbaikan pelayanan 
penanaman modal. Muncul Peraturan Menteri Dalam Negeri Nomor 100 Tahun 2016 tentang Pedoman Nomenklatur Dinas Penanaman Modal dan Pelayanan Terpadu Satu Pintu mendorong pemerintah daerah untuk melakukan penyesuaian. Dinas Perijinan dan Pelayanan Terpadu (DPT) Kabupaten Bantul terbentuk pada tahun 2007 dengan dasar hukum peraturan daerah Kabupaten Bantul nomor 16 tahun 2007 tentang pembentukan organisasi dinas daerah di lingkungan Pemerintah Kabupaten Bantul dan peraturan Bupati Bantul Nomor 20A tahun 2011 tentang rincian tugas, fungsi, dan tata kerja Dinas Perijinan Kabupaten Bantul.

Munculnya Peraturan Menteri Dalam Negeri Nomor 100 Tahun 2016 mendorong perubahan kelembagaan pelayanan terpadu dari Dinas Perijinan dan Pelayanan Terpadu menjadi Dinas Penanaman Modal dan Pelayanan Terpadu (DPMPT). Perubahan kelembagaan pelayanan terpadu menjadi Dinas Penaman Modal dan Pelayanan Terpadu diatur dengan dasar hukum Peraturan Bupati Bantul Nomor 123 Tahun 2016 Tentang Kedudukan, Susunan Organisasi, Tugas, Fungsi, dan Tata Kerja Dinas Penanaman Modal dan Pelayanan Terpadu Kabupaten Bantul. Rumusan permasalahan yang akan diangkat dalam penelitian ini adalah sejauh mana implementasi perubahan kelembagaan Dinas Pelayanan Terpadu Bantul dalam merespon kebijakan pemerintah pusat.

Reformasi birokrasi sebagai bagian dari reformasi dibidang politik,hukum, perekonomian, dan reformasi di bidang budaya organisasi. Keberhasilan ataupun kegagalan melaksanakan reformasi birokrasi sangat dipengaruhi oleh kegagalan melaksanakan reformasi di bidang yang lain. Namun birokrasi pemerintahlah yang akan mengimplementasikan hasil reformasi bidang yang lain (Rewansyah,2010:14). Reformasi merupakan suatu langkah perubahan tanpa merusak (to change without destroying) atau perubahan seraya memelihara (to change while preserving) yang diprakarsai oleh mereka yang memimpin suatu sistem karena sadar bahwa tanpa reformasi sistem itu bisa ambruk (Rasyid,1998:10).

Perubahan organisasi dalam kelembagaan secara umum dirumuskan oleh Hellriegel (1979) sebagaimana dikutip Winardi (2001:237) yang menyatakan bahwa perubahan keorganisasian yang direncanakan adalah suatu upaya yang diarahan pada tujuan tertentu,yang dilakukan suatu organisasi untuk mempengaruhi kondisi status status quonya sendiri atau status quo organisasi lainnya. Menurut Gareth R. Jones (2001;389) perubahan organisasi (organizational change) adalah proses dengan apa organisasi-organisasi beralih dari keadaan sekarang mereka menuju ke keadaan yang diinginkan pada masa mendatang, dengan tujuan meningatkan efektivitas mereka. Perubahan ditujukan untuk menemukan cara-cara baru atau cara-cara yang diperbaiki menggunakan sumber-sumber daya, dan kemampuan suatu organisasi untuk menciptakan nilai da memperbaiki hasil bagi para pemegang kepentingan (stakeholders).

Tjokroamidjojo (1997) mengemukakan pendayagunaan pelayanan publik oleh aparat birokrasi dapat dilakukan dengan 
cara (1) pengembangan pengukuran standar efisiensi, (2) perbaikan prosedur dan tata kerja rasional organisasi yang lebih efisien dan aefektif dalam manajemen operasional yang proaktif, (3) mengembangkan dan memantapkan mekanisme koordinasi yang efektif, (4) mengendalikan dan menyederhanakan birokrasi dengan management by exception dan minimize body contact dalam pelayanan jasa. Pengendalian, penyederhanaan dan perijinan yang perlu mendapat perhatian lebih dalam hal investasi, kegiatan usaha, pengelolaan tanah dan bangunan, serta kelancaran lalu lintas barang.

Kebijakan publik (Wibawa,1994) mengandung setidak-tidaknya tiga komponen dasar yaitu tujuan yang luas, sasaran yang spesifik dan cara mencapai sasaran tersebut. Cara merupakan komponen untuk mewujudkan komponen tujuan yang luas dan sasaran yang spesifik. Cara disebut juga implementasi kebijakan. Pressman dan Wildavsky (dalam Wahab, 1991) menyatakan bahwa implementasi adalah suatu proses interaksi antara suatu perangkat tujuan lebih lanjut dalam rangkaian sebab akibat yang menghubungkan tindakan dan tujuan, oleh karenanya interaksi antar elemen-elemen yang ada merupakan suatu hal yang vital dalam konsep implementasi. Secara sederhana dapat dikatakan implementasi merupakan suatu rangkaian kegiatan yang dilakukan untuk mengantarkan suatu program ke arah efek yang diharapkan dalam tujuan sebuah kegiatan.

Implementasi kebijakan (Wibawa,1994) terkandung beberapa komponen kebijakan yaitu:(1) siapa pelaksana atau implementornya, (2)berapa besar dana dan darimana diperolehnya, (3)siapa kelompok sasarannya,(4) sistem manajemen dan(5) keberhasilan atau kinerja kebijakan diukur. Untuk dapat menentukan tinggi-rendahnya kinerja implementasi suatu kebijakan maka penilaian terhadap kinerja implementasi terkait dengan pertanyaan (i) apa isi dan tujuan dari suatu kebijakan (ii) apa tahapan-tahapan yang harus dilakukan untuk mencapai tujuan tersebut; (iii) apakah setelah tahapan-tahapan tersebut dilakukan, implementasi yang dijalankan tadi mampu mewujudkan tujuan kebijakan atau tidak.

\section{B. Metode Penelitian}

Penelitian ini menggunakan penelitian jenis kualitatif eksploratif. Penelitian menggunakan kualitatif menurut Kirk dan Miller adalah tradisi tertentu dalam ilmu pengetahuan sosial yang secara fundamental bergantung kepada pengamatan manusia dalam bahasanya di dalam peristilahannya (Moleong, 1994). Penelitian menggunakan jenis kualitatif deskriptif. Penelitian deskriptif merupakan penelitian yang dimaksud untuk mengumpulkan informasi mengenai status suatu gejala yang ada yaitu suatu keadaan, gejala menurut apa adanya pada saat penelitian dilaksanakan. Penelitian deskriptif tidak dimaksudkan untuk menguji hipotesis tertentu tetapi hanya menggambarkan apa adanya tentang sesuatu variabel, gejala, keadaan (Suharsimi, 1990).

Data primer diperoleh melalui observasi lapangan dan wawancara terstruktur. Data sekunder diperoleh melalui studi dokumentasi, tabel, grafik serta berbagai literatur maupun informasi seputar 
reformasi kelembagaan Dinas Penanaman Modal dan Pelayanan Terpadu Bantul. Observasi dilakukan dengan pengamatan langsung terhadap proses pelayanan perijinan di Dinas Penanaman Modal dan Pelayanan Terpadu. Wawancara terstruktur dilakukan pada informan key person bidang-bidang terkait dalam struktur Dinas Penanaman Modal dan Pelayanan Terpadu Bantul sesuai dengan struktur kelembagaan, dinas teknis terkait, serta masyarakat yang pernah melakukan akses terhadap pelayanan. Wawancara akan dilakukan pada pada stakeholder Dinas Penanaman Modal dan Pelayanan Terpadu.

\section{Hasil Dan Pembahasan}

1. Perubahan Nomenklatur Dinas Penanaman Modal dan Pelayanan Terpadu Perijinan Kabupaten Bantul

Dinas Penanaman Modal dan Pelayanan Terpadu (DPMPT) Kabupaten Bantul berdiri dengan dasar hukum Peraturan Daerah Kabupaten Bantul Nomor 12 Tahun 2016 dan Peraturan Bupati Bantul Nomor 123 Tahun 2016 dan mulai beroperasi Januari tahun 2017. Sebelumnya Dinas Penanaman Modal dan Pelayanan Terpadu bernama Dinas Perijinan Kabupaten Bantul yang dibentuk berdasarkan Peraturan Daerah Kabupaten Bantul Nomor 16 tahun 2007 dan Peraturan Bupati Bantul Nomor 84 tahun 2007 dan beroperasi sejak tanggal 2 Januari 2008. Perubahan dari Dinas Perijinan menjadi Dinas Penanaman Modal dan Pelayanan Terpadu (DPMT) menyesuaikan dengan kebijakan pemerintah untuk mempermudah perijinan penanaman modal. Kebijakan dimplementasikan dengan terbitnya
Peraturan Menteri Dalam Negeri Nomor 100 Tahun 2016 tentang Pedoman Nomenklatur Dinas Penanaman Modal dan Pelayanan Terpadu Satu Pintu. Peraturan tersebut menegaskan bahwa nomenklatur lembaga perijinan untuk penanaman modal berbentuk Dinas Penanaman Modal dan Pelayanan Terpadu Satu Pintu dengan berbagai tipe yang menyesuaikan dengan kondisi dan kemampuan daerah.

Mengacu pada peraturan tersebut pemerintah daerah kabupaten Bantul merubah organisasi/nomenklatur Dinas Perijinan dan Pelayanan Terpadu (DPPT) Kabupaten Bantul menjadi Dinas Penanaman Modal dan Pelayanan Terpadu. Perubahan tersebut berlaku dengan dasar hukum Peraturan Daerah Kabupaten Bantul Nomor 12 tahun 2016 tentang Pembentukan dan Susunan Perangkat Daerah Kabupaten Bantul dan Peraturan Bupati Bantul Nomor 123 Tahun 2016 Tentang Kedudukan, Susunan Organisasi, Tugas, Fungsi, dan Tata Kerja Dinas Penanaman Modal dan Pelayanan Terpadu Kabupaten Bantul. Peraturan ini diperjelas dengan adanya Peraturan Bupati Bantul Nomor 123 Tahun 2016 menyebutkan bahwa mempunyai tugas membantu Bupati melaksanakan urusan pemerintahan yang menjadi kewenangan daerah dan tugas pembantuan bidang penanaman modal dan pelayanan terpadu. Terjadi peningkatan kewenangan Dinas dari memproses perijinan penanaman modal dan investasi menjadi memproses, mengeluarkan ijin dan melakukan evaluasi. Perubahan ini secara terlihat dari perbandingan tugas pokok dan fungsi Dinas Perijinan dan Dinas Penanaman Modal dan Pelayanan Terpadu Kabupaten Bantul sebagai berikut: 
Tabel 1 Perubahan Tugas Pokok dan Fungsi

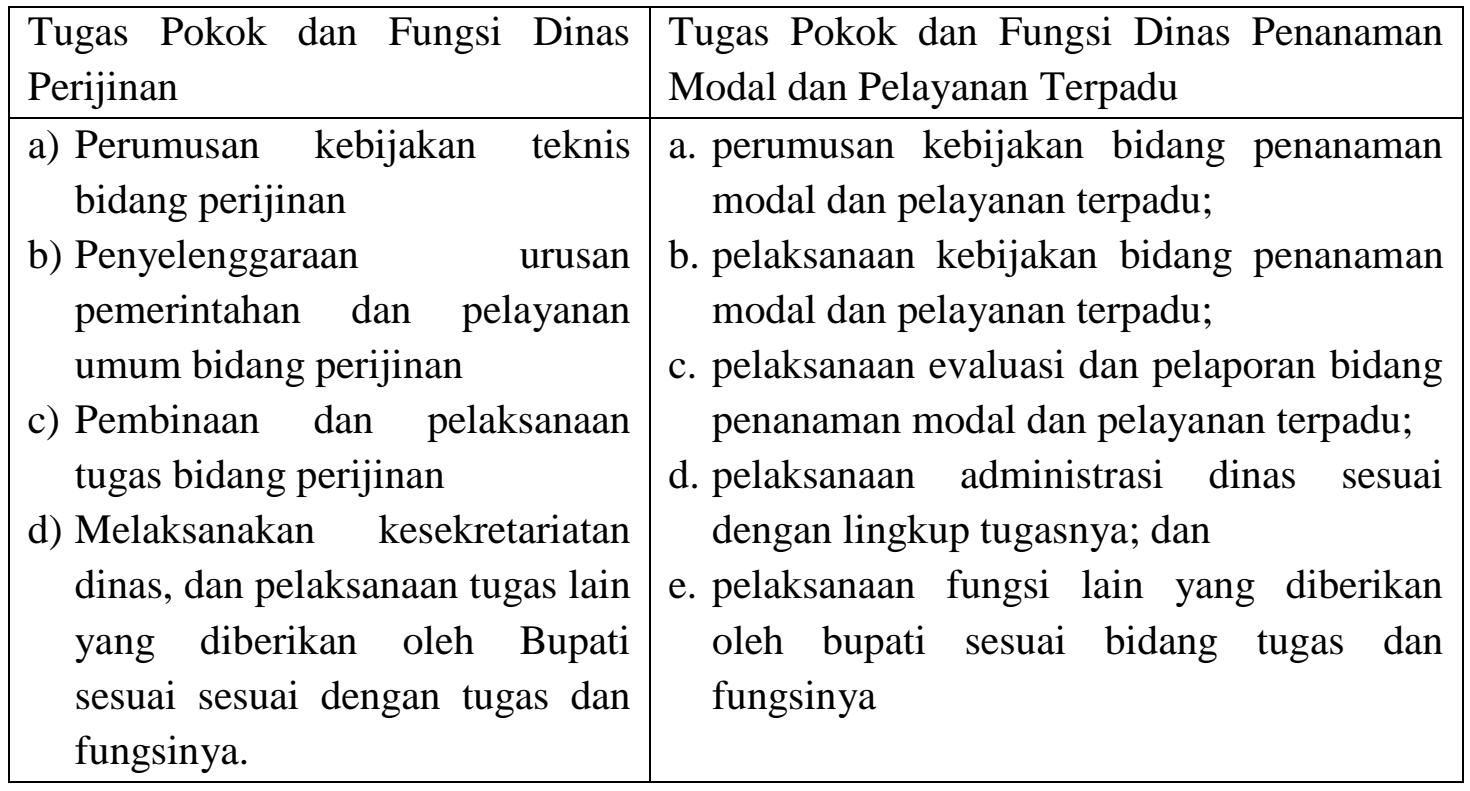

Sumber: Diolah dari Peraturan Bupati Bantul Nomor 84 Tahun 2007 dan Peraturan Bupati Bantul Nomor 123 Tahun 2016

Ada perubahan tupoksi dari perumusan kebijakan teknis bidang perijinan menjadi perumusan kebijakan bidang penanaman modal dan pelayanan terpadu. Terjadi peningkatan kewenangan bidang penanaman modal dari tupoksi penyelenggara menjadi pelaksana kebijakan. Dinas berwenang menyusun, melaksanakan dan melakukan evaluasi dan pelaporang bidang penanaman modal. Kajian kelembagaan Perijinan dan Penanaman Modal di Kabupaten Bantul (Kurniadi, 2011) kewenangan dinas perijinan bersifat sharing dengan dinas terkait. Hasil focus group discussion staf DPMPT menyebutkan bahwa dengan perubahan kelembagaan yang ada saat ini proses perijinan penanaman modal bisa selesai dalam 3 hari. Dinas terkait dalam hal ini Dinas Koperasi, Usaha Kecil Menengah, dan Perindustrian hanya memberikan rekomendasi sementara proses ijin ada Dinas Penanaman Modal dan Pelayanan Terpadu (DPMPT). Terjadi perubahan tugas pokok dan fungsi dari sekedar menangani tentang proses perijinan dan non perijinan secara umum dalam berhubungan dengan pemohon ijin, dengan sistem sharing kewenangan dengan instansi teknis dalam keputusan pemberian ijin.

\section{Struktur Organisasi dan Sumber Daya Manusia}

Perubahan kelembagaan pelayanan terpadu dengan fokus perbaikan pada pelayanan penanaman modal dan investasi juga berdampak pada perubahan struktur organisasi. Sebelumnya pelayanan terpadu mempunyai 1 sekretariat, dan 3 bidang (bidang pelayanan dan informasi; bidang pendataan dan penetapan; dan bidang pengaduan, pengawasan serta bidang pengendalian, dan bidang pelayanan dan informasi. Berdasarkan peraturan dinas perijinan masuk dalam klasifikasi dinas 
dengan tipe B. Setelah menjadi Dinas Pelayanan Modal dan Pelayanan Terpadu, dinas mempuyai 1 sekretariat, 4 bidang (dengan penambahan bidang penanaman modal) dan ditambah dengan kelompok jabatan fungsional. Kondisi tersebut membuat DPMT masuk dalam kategori dinas dengan tipe A. Perbedaan struktur tersebut dapat dilihat dalam bagan berikut:

Bagan 1 Struktur Organisasi Dinas Perijinan

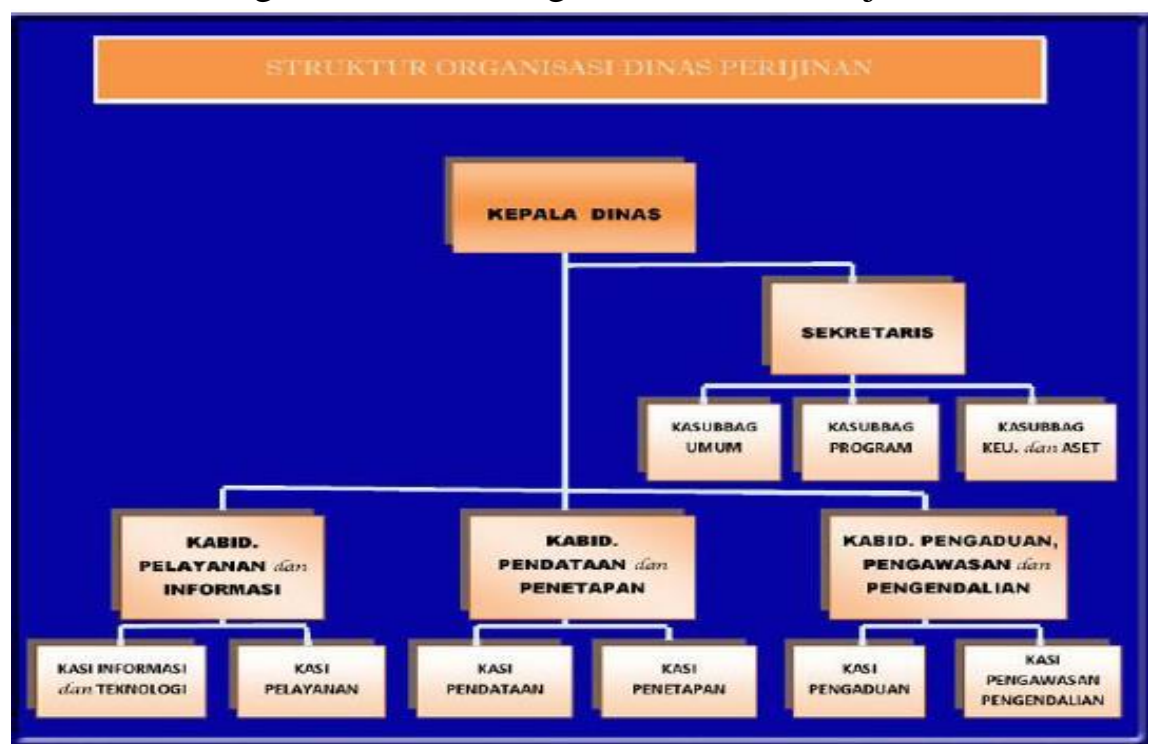

Sumber: (Kurniadi, 2011)

Bagan 2 Struktur Organisasi Dinas Penanaman Modal dan Pelayanan Terpadu

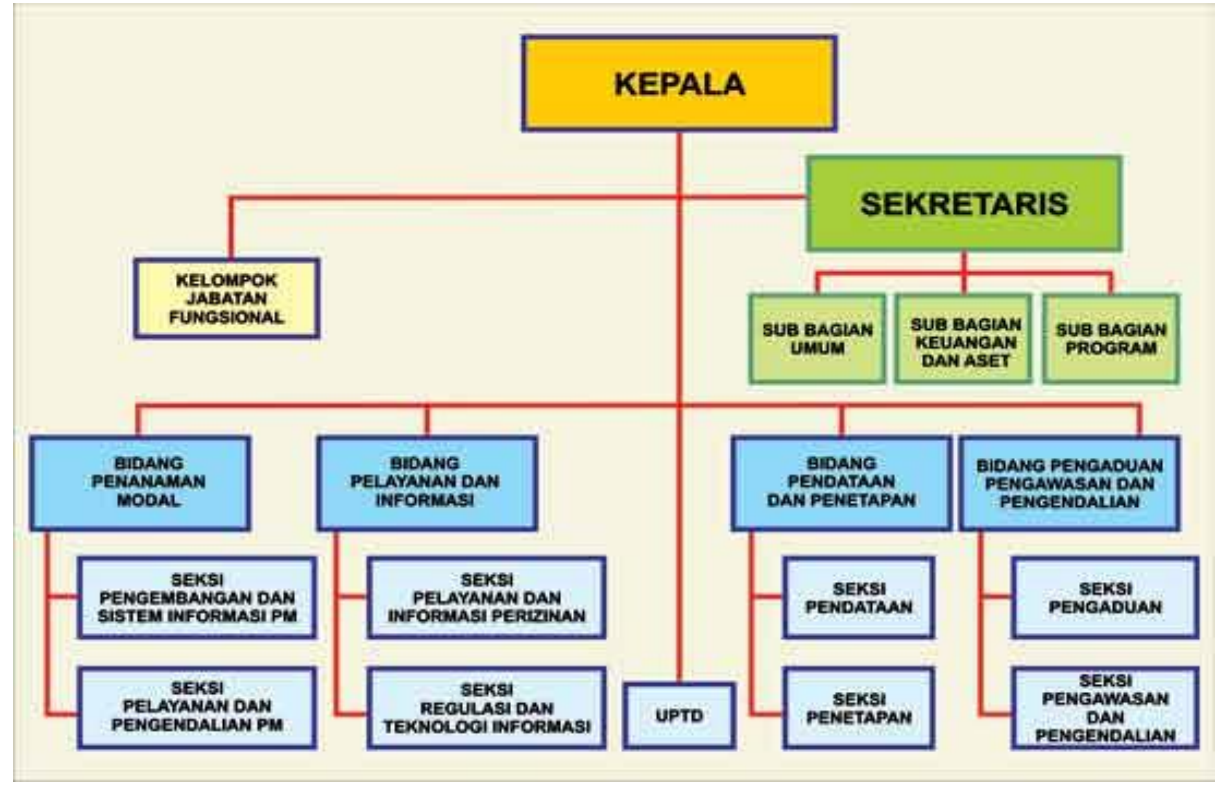

Sumber: website resmi Dinas Penanaman Modal dan Pelayanan Terpadu

Adanya penambahan kewenangan penanaman permodalan ternyata tidak banyak memberikan perubahan pada jumlah sumber daya manusia Dinas Penanaman Modal. Menurut penelitian (Kurniadi, 2011) jumlah pegawai saat 
kelembagaan Dinas Perijinan berjumlah 38 Berdasarkan wawancara dengan Kasubbag Program Wiwin Istiumaya saat ini jumlah pegawai Dinas Penanaman Modal dan Pelayanan Terpadu adalah 35 orang. Pengurangan jumlah pegawai terjadi karena adanya mutasi dan pensiun. Adanya penambahan kewenangan penanaman modal yang tidak diimbangi dengan penambahan jumlah pegawai disebabkan karena faktor anggaran pendapatan daerah (APBD) kabupaten Bantul yang alokasi anggaran untuk penggajian lebih dari $50 \%$ sehingga tidak memungkinkan untuk rekruitmen pegawai baru. Perubahan kelembagaan memunculkan adanya kelompok jabatan fungsional komputer sejumlah 4 orang. Saat ini belum ada kelompok unit pelaksana teknis Dinas meskipun strukturnya ada.

Perubahan struktur organisasi berupa penambahan bidang penanaman modal dengan seksi pengembangan dan sistem informasi penanaman Modal dan seksi pelayanan dan pengendalian. Perubahan juga terjadi pada penambahan tugas pokok dan fungsi bidang penanaman modal. Terjadi penambahan bidang tugas penanaman modal, kelompok jabatan fungsional dan UPT. Perubahan tugas pokok dan fungsi lembaga adalah adanya perubahan tugas pokok dari hanya perumusan kebijakan teknis bidang perijinan meningkat menjadi perumusan kebijakan bidang penanaman modal dan pelayanan terpadu. Perubahan tugas pokok dan fungsi menjadi lebih fokus pada penanaman modal dan pelayanan terpadu. Ada peningkatan tugas pokok dan fungsi dari pembinaan dan pelaksanaan tugas pada bidang perijinan menjadi pelaksanaan evaluasi dan pelaporan bidang penanaman modal dan pelayanan terpadu serta adanya administrasi dinas.

Terkait dengan jumlah SDM organisasi, perubahan nomenklatur dan kewenangan lembaga tidak ada penambahan SDM secara kuantitas. Menurut penelitian (Kurniadi, 2011:19) jumlah pegawai saat kelembagaan Dinas Perijinan berjumlah 38. Saat ini jumlah pegawai Dinas Penanaman Modal dan Pelayanan Terpadu adalah 35 orang. Pengurangan jumlah pegawai terjadi karena adanya mutasi dan pensiun. Adanya penambahan kewenangan penanaman modal yang tidak diimbangi dengan penambahan jumlah pegawai disebabkan karena faktor anggaran pendapatan daerah (APBD) kabupaten Bantul yang alokasi anggaran untuk penggajian lebih dari $50 \%$ sehingga tidak memungkinkan untuk rekruitmen pegawai baru. Perubahan kelembagaan memunculkan adanya kelompok jabatan fungsional komputer sejumlah 4 orang.

\section{Peningkatan Pelayanan Perijinan} a) Jumlah ijin yang dikelola

Hasil pengamatan peneliti menunjukkan perubahan kelembagaan yang terjadi dari Dinas Perijinan menjadi Dinas Pelayanan Terpadu dan Perijinan tidak berdampak pada penambahan atau pengurangan jumlah ijin yang dilayani. Jumlah ijin yang dilayani oleh Dinas Perijinan berjumlah 99 (Kurniadi, 2011). Saat ini DPMT mengelolo ijin sejumlah 98. Ada pengurangan 1 ijin yang dikelola yaitu 98 ijin. Dinas Penanaman Modal dan Pelayanan Terpadu (DPMPT) Kabupaten Bantul telah melayani 99 jenis izin dan non izin yang terdiri atas:

1. Perijinan Dasar : 4 jenis 
2. Perijinan Perdagangan dan industri: 13 jenis

3. Perijinan usaha dan jasa konstruksi: 3 jenis

4. Perijinan angkutan: 3 jenis

5. Perijinan bidang kesehatan: 53 jenis

6. Perijinan bursa kerja luar negeri: 1 jenis

7. Perijinan penjualan minuman beralkohol: 2 jenis

8. Perijinan usaha perikanan: 7 jenis

9. Perijinan Usaha Perikanan: 7 jenis

10. Usaha Pariwisata: 13 jenis (Laporan Akuntabilitas Kinerja Instansi Pemerintahan Dinas Perijinan Kabupaten Bantul, 2016).

\section{b) Proses Percepatan Pelayanan Perizinan}

Penelitian Handayani (2015) tentang Implementasi Sistem Pelayanan Perizinan Paralel di Kabupaten Bantul menemukan bahwa telah diimplementasi sistem pelayanan perizinan paralel untuk pengembangan investasi di Dinas Perijinan Kabupaten Bantul. Ini berarti sebelum adanya perubahan kelembagaan telah dilakukan upaya mempercepat perijinan penanaman modal dengan implementasi perizinan parallel. Hasil penelitian ditemukan bahwa dengan peningkatan kewenangan dalam kebijakan pengembangan penanaman modal dan investasi proses perijinan bisa diselesaikan dalam waktu 3 hari. Ini lebih cepat dari target waktu yang diamanatkan dalam Peraturan Menteri Dalam Negeri Nomor 100 Tahun 2016 yaitu 7 hari.

\section{Kesimpulan}

Perubahan kelembagaan pelayanan terpadu pemerintah Kabupaten Bantul dari Dinas Perijinan menjadi Dinas Penanaman
Modal dan Pelayanan Terpadu dilatar belakangi oleh adanya kebijakan pemerintah pusat untuk pengembangan investasi berupa aturan nomenklatur lembaga pelayanan terpadu sebagai Dinas Pelayanan Terpadu dan Penanaman Modal.Perubahan yang terjadi setelah adanya perubahan kelembagaan adalah adanya perubahan nomenklatur lembaga dari Dinas Perijinan menjadi Dinas Penanaman Modal dan Pelayanan Terpadu penambahan jumlah bidang dari 3 bidang menjadi 4 bidang yaitu penambahan bidang penanaman modal yang terdiri dari seksi pengembangan dan sistem informasi penanaman modal dan seksi pelayanan dan pengendalian penanaman modal. Juga terjadi penambahan jabatan fungsional pranata komputer dan struktur unit pelayanan dinas (UPTD).Penambahan bidang dan struktur yang lain berdampak pada penambahan tugas pokok dan fungsi terkait dengan penanaman modal dan informasi.

Penambahan kewenangan dalam bidang penanaman modal yang pada masa Dinas Perijinan hanya melayani proses perijinan dengan sharing kewenangan di Dinas Penanaman Modal, perindustrian dan koperasi. Saat ini kewenangan tersebut dilaksanakan oleh Dinas Penanaman Modal dan Pelayanan Terpadu dengan rekomendasi teknis dari Dinas Perindustrian, Perdagangan dan Koperasi.Menurunnya jumlah perijinan yang dilayani oleh Dinas Penanaman Modal dan Pelayanan Terpadu dari 99 jenis perijinan menjadi 98 perijinan dengan tidak adanya ijin gangguan (HO).Kebijakan tidak adanya ijin gangguan $\mathrm{HO}$ merupakan kebijakan dari 
pemerintah pusat untuk mempercepat proses pelayanan penanaman modal.

Perubahan kelembagaan yang disertai penambahan kewenangan penanaman modal tidak disertai dengan penambahan jumlah sumber daya manusia lembaga. Bahkan jumlah SDM berkurang dengan ada pegawai yang pensiun dan mutasi. Kondisi ini disebabkan oleh adanya beban anggaran gaji pegawai pemerintah kabupaten Bantul yang melebihi 50 persen dari total APBD sehingga tidak bisa mengajukan penambahan pegawai.

Kebijakan tidak adanya rekruitmen pegawai sipil untuk daerah yang beban anggaran gaji pegawai melebihi 50 persen dari APBD dengan pengadaan pegawai honorer. Perlu adanya optimalisasi teknologi dan sistem informasi untuk mengoptimalkan kinerja dinas penanaman modal dan meminimumkan jumlah SDM pegawai.

\section{Daftar Pustaka}

Nurcholis, hanif. 2005. Teori dan Praktek Pemerintahan dan Otonomi Daerah.

Jakarta:Grasindo,Gramedia Widiasarana.

Tjokroamidjojo, Bintoro. 1997.

Manajemen Pembangunan, Jakarta: Haji Mas-agung

Winardi,2001. Motivasi dan pemotivasian dalam Manajemen, Jakarta, Raja Grafindo Persada

Jones, Gareth R.2001, Organizational Theory;Text and Cases, New Jersey,Prentice-Hall

Cole and Parston.2006. Unlocking Publik Value. New Jersey and etc: John Wiley and Son.
Rewansyah, Asmawi. 2010. Reformasi Birokrasi dalam Rangka Good Governance.Jakarta:Yusaintanas Prima)

Rasyid,Ryaas M. 1997. Perkembangan Pemikiran tentang Masyarakat Kewarganegaraan. Jurnal Ilmu Politik.

Kurniadi, Bayu Dardias, Nur Azizah, Andi Antonius Tabusassa Tonralipu. 2011. Laporan Akhir:Penyusunan Kelembagaan Badan Pelayanan Perijinan Terpadu dan Penanaman Modal.Jurusan Ilmu Politik dan Pemerintahan Fakultas Ilmu Sosial dan Ilmu Politik UGM. Yogyakarta.

Kriswantoro dan Sugi R. 2012.Strategi Reformasi Birokrasi Sektor Pelayanan Publik di Dinas Perizinan Kota Ygyakarta. Jurnal Adinegara. Moleong, Lexy.1994. Metodologi Penelitian Kualitatif, Remaja Rosdakarya, Bandung, cetakan kelima.

Sudaryanti, Tri.2012.Pengembangan

Pelayanan Publik Berbasis

Partisipasi Masyarakat (Studi

Penelitian di Dinas Perijinan

Kabupaten Bantul).Jurnal Riset

Daerah Vol XI. No.2 Agustus 2017 Yogyakarta

Singarimbun, M. 1995. Metode Penelitian Survey. Jakarta:LP3ES

Suharsami, 1990, Manajemen Penelitian, Rineka Cipta, Jakarta

Winarno, Budi. 1984. Teori Kebijakan Publik. PAU, Studi Sosial UGM. Yogyakarta.

Wahab, Solihin Abdul. 1991. Pengantar Analisis Kebijakan Negara, Jakarta: Sinar Grafika

Wibawa, Samodra, Yuyun Purbo Kusumo, dan Agus Pramusinto. 1994. Evaluasi 
Kebijakan Publik. Jakarta:PT Raja grafindo Persada 2015.Laporan Akuntabilitas

Dinas Perijinan Kabupaten Bantul. Dinas Perijinan Kabupaten Bantul.Yogyakarta dalam Peraturan Bupati Bantul Nomor 123 Tahun 2016

Website:

http://perijinan.bantulkab.go.id/ diakses tanggal 1 Juni 2017

\section{Peraturan - peraturan}

Undang-Undang No. 25 Tahun 2007 tentang Penanaman Modal

Undang-undang Nomor 25 tahun 2009 tentang Pelayanan Publik

Peraturan Pemerintah Nomor 96 Tahun 2012 tentang Pelaksanaan UU No.25 tentang Pelayanan Publik

Peraturan Presiden No. 97 tahun 2014 Penyelenggaraan Pelayanan Terpadu Satu Pintu

Peraturan Menteri Dalam Negeri Nomor 100 Tahun 2016 tentang Pedoman Nomenklatur Dinas Penanaman Modal dan Pelayanan Terpadu Satu Pintu

Peraturan Bupati Bantul Nomor 84 Tahun 2007 tentang Rincian Tugas, Fungsi Dan Tata Kerja Dinas Perijinan Kabupaten Bantul.

Peraturan Bupati Bantul Nomor 123 Tahun 2016 Tentang Kedudukan, Susunan Organisasi, Tugas, Fungsi, dan Tata Kerja Dinas Penanaman Modal dan Pelayanan Terpadu Kabupaten Bantul

Peraturan Daerah Kabupaten Bantul Nomor 12 Tahun 2016 tentang perubahan perangkat daerah. Peraturan yang berisi mengenai kedudukan, susunan organisasi, tugas dan fungsi, serta tata kerja perangkat daerah yang merupakan isi dan tujuan kebijakan diatur 